\title{
THE 1883 CONVENTION AND THE IMPOSSIBLE UNIFICATION OF INDUSTRIAL PROPERTY
}

\author{
Gabriel Galvez-Behar (Université de Lille - Institut universitaire de France)*
}

Pre-print version

Pre-print version. For quotation, please refer to : Gabriel Galvez-Behar. "The 1883 Paris Convention and the Impossible Unification of Industrial Property" in Gooday, Graeme; Wilf, Steven (eds). Patent Cultures: Diversity and Harmonization in Historical Perspective, Cambridge University Press, pp.38-68, 2020. \{10.1017/9781108654333.003〉.

\section{Introduction}

In 1994 the Agreement on Trade Related Aspects of Intellectual Property Rights (TRIPs) was concluded under the aegis of the World Trade Organization (WTO). It created a multilateral framework for intellectual property rights (IPRs) 'to ensure that measures and procedures to enforce intellectual property rights do not themselves become barriers to legitimate trade.' ${ }^{1}$ This global framework quickly came in for criticism as the imposition of a western regime of intellectual property rights, characterized by an extension of the domain of patentability to new activities and ends, in a form of neo-colonialism. ${ }^{2}$ This model has been strongly condemned in a critical history of intellectual property law, that refuses to consider TRIPS as the inevitable outcome of a teleological process. ${ }^{3}$

The history of intellectual property is characterized by an early international regulation, with the setting up of the Paris Union in 1883 and its Convention on Patents and Trademarks, and in 1886 the Berne Union and its Convention for the Protection of Literary and Artistic Works. In this sense it lends itself well to a teleological perspective. For some, these two Conventions mark the first experience of developing countries with an international regime of intellectual property. ${ }^{4}$ For others, given that they were finalized when the western powers were carving up Africa and the world, they carry the seed of an imperialist vision of industrial property. ${ }^{5}$ It gives us an interesting comparison: TRIPS was to neo-colonialism what the Paris and Berne Unions were to imperialism.

Yet this analogy poses problems and threatens to revive the teleological perspective which we claim to discard. To what extent were the Paris and Berne Unions really forms of imperialism? How were the territories under western domination in the nineteenth and twentieth centuries integrated with the development of intellectual property rights? This presentation focuses on elements for reflection when answering these questions on patent rights for inventions. After having examined the expansion of patent law at the international level, we focus on the development of the Paris Union.

\footnotetext{
* I have to thank Clare Tame for the translation of this text.

1. TRIPS, Preamble, http://www.wto.org/english/docs e/legal e/27-trips 02 e.htm.

2. Vandana Shiva, Protect or Plunder? Understanding Intellectual Property Rights, Brooklyn, Zed Books, 2002; Susan K. Sell, Private Power, Public Law: the Globalization of Intellectual Property Rights, Cambridge, CUP, 2003; Carolyn Deere, The Implementation Game: The TRIPS Agreement and Global Politics of Intellectual Property Reform in Developing Countries, Oxford, OUP, 2008.

3. Christopher May and Susan K. Sell, Intellectual Property Rights. A Critical History, Boulder/London, Lynne Riener, 2006.

4. Carolyn Deere, The Implementation Game, op. cit., p. 37.

5. Doris Long, 'Exposing the Processes of Empire in the International Protection of Intellectual Property' in Debora Halbert and William Gallagher (eds), Law and Society Perspectives on Intellectual Property, Cambridge, CUP, forthcoming; Doris Long, 'The Continuation of the Geographic Boundaries of Empire in the New Digital Order', International Society for the History and Theory of Intellectual Property Workshop 2010, paper given on 24 September 2010.
} 


\section{The internationalization of patent rights in the nineteenth century: a multi-level game}

The history of the patent has taken place over a long period, which remains the introduction of the Venitian patent statutes in 1474. Yet it is the nineteenth century that stands out as the century of the patent. ${ }^{6}$ Between 1896 and 1912 the Recueil général de la législation et des traités concernant la propriété industrielle (General Collection of Legislation and Treaties on Industrial Property) published a summary of the state of legislation on patents throughout the world in the nineteenth century. ${ }^{7}$ Although it is difficult to give exact dates, particularly given major changes on the map of Europe and the world, and despite the limitations and heterogeneity of the laws, we can still detect several periods and models in the global spread of patent legislation and its affirmation.

\subsection{The contrasting expansion of the patent regime}

Three periods stand out in this process. The first takes place in the first half of the nineteenth century, during which several European and American countries drafted patent legislation. The three founding countries (Great Britain, United States and France) were joined by Italy, Germany, and Russia (1812), the Netherlands (1817), and Spain (1810-1826). ${ }^{8}$ At the end of the eighteenth century Great Britain was the generally recognized standard for inventor's rights and the British model inspired American and French revolutionaries. ${ }^{9}$ In France chevalier de Boufflers stressed the English example in his Rapport sur la propriété des auteurs de nouvelles découvertes et inventions en tout genre d'industrie presented to the Constituent Assembly. For him, the law on patents had made England 'a great corporation of arts and trades: a fearful association, where the most skilled craftsmen and the best manufacturers and above all the most inventive geniuses of all nations [rushed] to join. ${ }^{10}$ As competitor and model, England promoted its industry by attracting foreign inventors. France would have to follow its example in drafting its own law on inventions.

In spite of the strength of the English model, the French patent law of 1791 is one of the format of patent rights in nineteenth century continental Europe. The Napoleonic wars imposed the French model de facto in the territories annexed to the Republic, and then the Empire. In occupied countries French influence was also strong. In Spain, a Royal Decree on patents of 1811 was largely based on the French law. Even if a return to the system of privileges was tried in 1820, a new law adopted the liberal and French model six years later. ${ }^{11}$ The situation was much the same in the Kingdom of Naples where a Royal Decree of 2 March 1810 based the main part of its content on the French law.

The Vienna Congress did not challenge the contribution of French legislation. In 1817 the Netherlands adopted legislation largely based on the 1791 law. The situation in the Germanic Confederation was more divergent. Rhenish Baveria remained subject to French law of 1791, whereas in Prussia the rights of inventors were governed by a 1815 publicandum. The rest of Bavaria adopted a law on industry in 1825 authorizing the granting of patents. However, the progressive emergence of the Zollverein imposed the implementation of an agreement in 1842 to avoid all exchange barriers while protecting the invention of machines. ${ }^{12}$

We should also note the emergence of patent law in South American countries such as Brazil (1806-1824),

6. Yves Plasseraud and François Savignon, L'État et l'invention, histoire des brevets, Paris, Le Seuil, 1982; Alain Beltran, Sophie Chauveau and Gabriel Galvez-Behar, Des brevets et des marques. Une histoire de la propriété industrielle, Paris, Fayard, 2001.

7. Bureau international de l’Union pour la protection de la propriété industrielle, Recueil général de la législation et des traités concernant la propriété industrielle, Berne, 7 vols., 1896-1912.

8. G. Galvez-Behar, 'Controverses et paradoxes dans l'Europe des brevets au XIX ${ }^{\mathrm{e}}$ siècle', Innovations et transferts de technologie en Europe du Nord-Ouest aux XIXe et XXe siècles, eds. Jean-François Eck and Pierre Tilly, Brussels/Berne/Berlin/Frankfurt a.M., New York/Oxford/Vienna, Peter Lang, pp. 35-51.

9. G. Galvez-Behar, 'Genèse des droits de l'inventeur et promotion de l'invention sous la Révolution française', April 2006, http://halshs.archives-ouvertes.fr/halshs-00010474/en/, consulted 21 February 2014; C. Demeulanaere-Douyère 'Inventeurs en Révolution: la Société des inventions et découvertes', Documents pour l'histoire des techniques, 17(1) 2009, pp. 19-56.

10. G. Galvez-Behar, 'Genèse des droits’, op. cit; C. Demeulanaere-Douyère 'Inventeurs en Révolution', op. cit.

11. Patricio Saiz-Gonzalez, Invención, patentes e innovación en la España contemporánea, Madrid, Oficina Española de Patentes y Marcas, 1999.

12. Alfred Müller, Die Entwicklung des Erfindungsschutzes und seiner Gesetzgebung in Deutschland, Munich, Lindauer, 1898; Alfred Heggen, Erfindungsschutz und Industrialisierung im Preußen, 1793-1887, Göttingen, Vandenhœck \& Ruprecht, 1975 ; Margrit Secklemann, Industrialisierung, Internationalisierung und Patentrecht im Deutschen Reich 1871-1914, Francfurt-on-Main, Vittorio Klostermann, 2006 
Argentina (1826), and Mexico (1832). The newfound independence of these old Spanish and Portuguese colonies did not inhibit the recognition of inventors' rights, which were sometimes written into the Constitution of the country itself (Brazil 1824; Chile 1833). To some extent, this development took place in the wake of founding legislation: several European laws took a good number of their measures from the 1791 French law while the recognition of inventors' rights in the Peruvian (1828) and Chilean constitutions (1833) echoed the recognition stipulated in the constitution of the United States.

The second period runs from the 1850s to the early 1880s with the introduction of patent law in the British and French colonies. Some countries in Latin America continued to draft their own patent laws, like Uruguay (1853), Venezuela (1878), but it was in New South Wales (1852), Jamaica (1857), and the Cape that we really see patents recognized. In this period the colonial powers were using a number of methods to develop legal devices to protect inventions in their colonies. At times they exported their own model, based on that of France, where the 1844 law largely inspired the law passed in the Ottoman Empire in 1879. ${ }^{13}$

Finally, the last period began in the 1880s. It is marked by a clear acceleration in the spread of patent legislation: half the territories with patent laws in 1901 had passed them between 1880 and 1900. Some European states, such as Switzerland and Denmark, end up adopting a law on patents in this period, but it is primarily the colonial powers that account for this acceleration; at the same time that, in particular Great Britain and France, were consolidating their carve-up of Africa. Things can however be more intricate and came to moderate this 'diffusioniste' model. For example, Japan's first patent law in 1885 excluded foreigners. Faced with this situation, the International Bureau for the Protection of Industrial Property could not hide his concern:

We can hope that this situation will change in the not too distant future, because some governments have been averted to the damage caused to their nationals by such a state of affairs. We should not forget that the Japanese are well informed and very up-to-date in industrial matters. In recent years their manufacturing [industry] has developed extraordinary rapidly. So they are inclined to seize the most recent and most important foreign inventions, [...] free of charge and with total impunity. ${ }^{14}$

The signing of the new trade treaty between Japan and Great Britain in 1894 was an opportunity for the latter to promote the protection of its nationals and to let Japan join the Paris Union.

So, in the early twentieth century, the greater part of the world granted inventors recognized rights, even if some countries still remained without legislation. In Europe, the Netherlands abolished its patent law in 1869, whereas Bulgaria, Greece, Rumania and Serbia had none. In Africa, Egypt, Madagascar and Morocco did not have specific law on patents, although in Egypt, the courts governing relations between Egyptians and foreigners, or among foreigners, managed the registration of inventions. At the start of the twentieth century in Asia, China and Persia had no patent law.

This synthetic overview suggests a link between the process of colonisation and the spread of patent law. As soon as communities of colonials producing their own inventions or importing more manufactured goods from the parent state emerge, in one territory or another, a need emerges for rules to manage conflicts between colonials or to combat native counterfeiting, as in the case of Japan. However, this process was not linear and turned out to be much more complex than the mere adoption of laws or the proclamation of regulations. To understand it, we need to change level of analysis.

This extension of patent law led to a quantitative expansion of the number of patents at the European and global levels which was reflected in a number of statistical observations. The limits of the latter are well known. ${ }^{15}$ Their temporal and spatial aggregation, tends to mask the heterogeneous nature of the legislation. A patent issued after prior examination does not have the same value as a patent issued almost automatically. Moreover, the statistical sources are sometimes contradictory. Data collected in 1964 by Pasquale Joseph Federico, then in charge of the American patent office, reveal contradictions when compared with national sources. ${ }^{16}$ The data collected by the Bureau of the Paris Union, published in La Propriété industrielle then

13. H. Raclot, Brevets d'invention. Aperçu général et droit comparé, Brussels/Paris, E. Bruylant - A. Pédone, 1905, p. 614.

14. International Bureau of the Union for the Protection of Industrial Property, Recueil général de la législation et des traités concernant la propriété industrielle, Vol. 2, Berne, 1897, p. 717.

15. François Caron, Les brevets. Leur utilisation en histoire des techniques et en économie, Paris, CNRS, 1984; Zvi Griliches, 'Patents Statistics as Economic Indicators: A Survey', Journal of Economic Literature, Vol. 38, December 1990, pp. $1661-1707$.

16. P. J. Federico, 'Historical Patent Statistics', The Journal of the Patent Office Society, 1964. 
taken up by the World Industrial Property Organization, contains information from the end of the nineteenth century. Despite these constraints, we can detect some trends and draw some lessons from this data on the condition that we take it for what it is: a measure of the use of a legal mechanism to protect inventor's rights.

Figure 1: Number of patents issued in the world and some European countries, 1791-1900

Source: P. J. Federico, 'Historical Patent Statistics', op. cit. European countries are Germany, Belgium, France, the Netherlands and the United Kingdom.

The data point to three types of characteristics: a globally exponential trend; national differences; and different timing. Starting in the late nineteenth century the number of patents multiplied by almost 600 at the world and European level. Several phenomena explain this trend: the 'innovatory dynamic' specific to the period; the extension of legislation on patents; and the reforms of patent law. The French reform of 1844 lowered the real cost of patents and thus allowed a rapid increase in the number of applications. The same applied to the Belgian laws of the 1850s, and the British reform of 1852. Yet this growth was not constant. If political crises had a strong impact, as the development of the number of patents after 1848 seems to suggest,

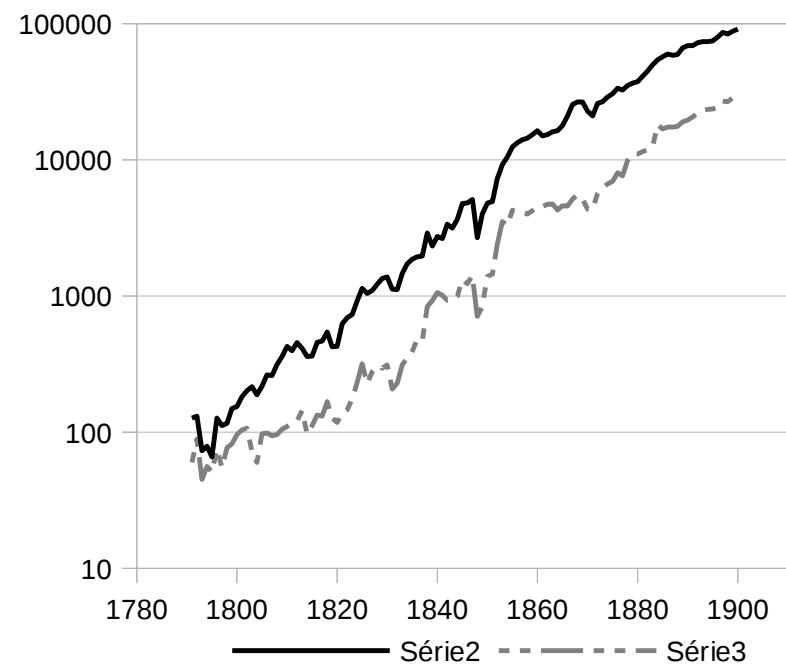

we can make out different periods. In the period 1800-1840 the increase was slow due to the small number of countries with patent legislation, its cost and the pace of industrialization. The years 1840-1850 mark a new phase: the number of patents increased at the same time as countries undertake reforms facilitating the issue of patents. In the period from 1850 to the 1870s the number of patents issued in the main countries in North-West Europe (Great Britain, France, the German states, Belgium and the Netherlands) stagnated. After the Franco-Prussian war, the number of patents again rose rapidly while a new technical system was taking shape.

\subsection{Heterogeneous legislation, localized dynamics}

In spite of this general trend, patent law conserved marked differences as regards the principles and on a practical level. The existence of a prior examination is a good measure of the philosophy underlying each national patent system. France stands out for its original refusal of such a procedure likened to a censure worthy of the ancien régime. With some exceptions, protection of the inventor's property was considered a natural right that government should not deter a priori. Only the courts could annul a patent or deprive the holder of his rights. The patent was thus issued Sans Garantie du Gouvernement (without government guarantee) - the famous SGDG - to risks and dangers of the applicant. The same was true for Belgium. In Great Britain, on the other hand, even after the reform of, a system of objection theoretically allowed the patent to be challenged before its definitive issue. Lastly, in Prussia patents were issued subject to an examination to evaluate the innovatory nature of the invention: the patent was still seen as a privilege conferred by the state.

It was not only a question of different principles. There were other key disparities. In the early 1860s, the maximum duration of protection varied from 15-20 years in most of North-Western Europe. The status of the foreign inventor also varied. In Great Britain, France and Belgium foreigners had the right to be patent holders, whereas in Prussia this was limited to Prussian citizens. Lastly, the cost of patents differed from one country to another. Faced with such disparities, entrepreneurs needed a thorough knowledge of the 
regulations which intermediaries, starting with patent agents, guaranteed. Besides variations in the costeffectiveness of patents, there was the question of the socially differentiated access to the protection of inventors' rights and their impact on economic performance : anyone was not capable of describing a technology and of managing industrial property.

\begin{tabular}{|c|c|c|c|c|}
\hline & Great Britain & France & Belgium & Prussia \\
\hline Maximum duration & $\begin{array}{c}\text { 14 years (7-year } \\
\text { extension possible) }\end{array}$ & 15 years & 20 years & 15 years \\
\hline Prior examination & $\begin{array}{c}\text { Yes (system of } \\
\text { opposition) }\end{array}$ & No & No \\
\hline Minimum cost & $5 £(125 \mathrm{~F})$. & $100 \mathrm{~F}$. & $10 \mathrm{~F}$. & $\begin{array}{c}\text { Administrative } \\
\text { registration fees }\end{array}$ \\
\hline Maximum cost & $175 £(4375 \mathrm{~F})$ & $1500 \mathrm{~F}$ & $2110 \mathrm{~F}$ & - \\
\hline Right of foreigner & Yes & Yes & Yes & No \\
\hline
\end{tabular}

Table 1: Some characteristics of patents, 1859

Source: Charles Renouard, 'Brevets d'invention' in Dictionnaire universel, théorique et pratique du commerce et de la navigation, Vol. 1, A-G, Paris, Guillaumin, 1859, pp. 410-411.

In addition to these disparities between different national legislative regimes there was also a marked spatial concentration of patent holders. For example, in Great Britain around $60 \%$ of patents were concentrated in London and the London area from the early nineteenth century onwards. The same applied to France where Paris accounted for up to two-thirds of patents issued in France in the entire nineteenth century, far exceeding other industrial areas such as the Rhône or Bouches-du-Rhône. Thus, from a legal perspective and as regards usage, the distribution of the patent mechanism was far from homogeneous. Theoretically valid on a national scale, it supports a limited number of places of which colonies are rather distant.

\subsection{The question of colonies}

Contrary to a generally accepted idea, patent law was not always imposed by the colonial powers on their colonies. ${ }^{17}$ It was more complex since the patent was both a stake and a mode of regulating economic competition between the colonies and their parent states. The distance often separating the colonies from their parent states favoured the adoption of local law to regulate technical exchanges within colonial economies, and even in more extensive spaces, straddling several colonies within the same geographical area. While we cannot launch into a detailed analysis of the use of patents in colonial spaces here, we will mention some points in the cases of the French, British and Spanish colonial empires.

French legislation adopted under the Revolution did not take colonies into account and the laws of 1791 had not been promulgated there. 'Thenceforth, the right to use any new discovery or invention, made in the parent state, far from belonging exclusively to its author, had fallen within the colonial public domain. ${ }^{18}$ In fact, between 1791 and 1844, only six patents were issued to colonials resident overseas out of a total of 17,007 patents issued in the period. ${ }^{19}$ However, some colonies felt the need to benefit from legal measures on patents. In 1831, the governor of the île Bourbon, Étienne-Henri Mengin du Val d'Ailly, issued an order allowing inventors to obtain a temporary title from the colonial government until obtaining a patent from the Royal government. This was clearly motivated by the governor's will to promote local industry, as evidenced by the creation of a Trade Council on his arrival, but perhaps also by the importance of local works on sugar production. ${ }^{20}$ Four years later, Mengin du Val d'Ailly vainly drew the royal government's attention to the gaps in the legislation on intellectual property in the île Bourbon and take the initiative to grant local patents. ${ }^{21}$

The situation changed gradually in the 1840s. The adoption of the new patent law of 5 July 1844 was a first milestone since Article 51 provided that Royal orders could regulate patent applications in the colonies. The advent of the Second Republic and its assimilationist spirit accelerated the process: in 1848 an order of the

17. Carolyn Deere, The Implementation Game, op. cit., p. 34.

18. Delabarre de Nanteuil, Législation de l'île de la Réunion, vol. 1, Paris, E. Donnaud, 1861, pp. 203-204.

19. Database analysis XIX ${ }^{\mathrm{e}}$ INPI. Five of the six patents were issued between 1841 and 1844.

20. Jean-François Géraud, 'Joseph Martiel Wetzell (1793-1857)’, Revue historique des Mascareignes, 1, 1998, pp. 1-38.

21. Delabarre de Nanteuil, Législation de l’île de la Réunion, op. cit., p. 204. 
Council of Ministers of 21 October extended the application of the 1844 law to all the colonies, on the condition that it be decreed in situ. ${ }^{22}$ This order was then decreed in Martinique (3 February 1849), Guadeloupe (26 January 1849), Réunion (20 April 1849), Guyana (7 March 1849), and India (10 February 1849). ${ }^{23}$ We must wait until 1880 for a ruling of the Supreme Court to consider the promulgation in the colonies which had not promulgated (in particular Senegal) as acquired.

The United Kingdom differed from the French case in that it was more inclined to keep local legislation. ${ }^{24}$ Before the reform of the patent law in 1852, the United Kingdom had two coexisting modes of issuing patents, in the parent state, where patents could be issued in England — but also in Ireland or Scotland—and in the colonies. The parliamentary debates of 1851 highlight the issue of colonial patents. The draft law which tended to homogenize the right of patents to the British standard, did not deal with the colonies. This met with sparked stiff opposition from parent-state sugar refiners who feared that their colonial competitors would profit free of charge from techniques invented by them. On the other hand, colonial plantation owners were keen to use these techniques gratis to offset competition from Cuban and Brazilian plantation-owners. Parent-state sugar refiners managed to have colonies included in the 1852 law, but on condition that patents issued in the parent state should not be invalidated with regard to the domestic regulations in place in colonies already with patent law. ${ }^{25}$

\begin{tabular}{|l|l|l|}
\hline & With legislation & Without legislation \\
\hline Colonies and possessions & $\begin{array}{l}\text { Cape of Good Hope, Canada and other } \\
\text { North American countries } \\
\text { Jamaica, Barbados, British Guinea } \\
\text { the East Indies, Australian territories }\end{array}$ & $\begin{array}{l}\text { African colonies, Falkland Islands } \\
\text { Zong Kong, the West Indies, New }\end{array}$ \\
\hline
\end{tabular}

Table 2: The patent in the British colonies (1853). Source: Coulter, 1991, p. 168.

In 1853, the British government launched a survey with the governors of around forty colonies and British possessions, asking them to describe the state of industrial property in situ and to consider the wisdom of extending British law. This consultation ended for the greater part in the rejection of any extension. The colonies without patent law, like the governor of the Gold Coast, considered it of no use in their territories, whereas colonies already with a legal framework for patents did not want to see it replaced. Besides, some plantations owners pointed out that the planned extension carried the risk of reducing their competitive edge over competitors, particularly when it came to preventing them from using patented material produced abroad. ${ }^{26}$

The particular situation of sugar-producing colonies also applied to Spanish colonies. ${ }^{27}$ In 1833, a Royal Charter extended the 1826 Decree reforming the right of patents to three overseas territories: Cuba, PuertoRico and the Philippines. However, Article 2 of the [Royal] Charter stipulated one notable exception:

Given the particular state of the Island of Cuba, it is not necessary to stimulate the development of the agricultural industry, mainly in sugar manufacturing, since both planters and institutions pay a great attention to foreign advances, taking and adopting machines, instruments, artefacts, scientific processes and methods, thus privileges are limited in Cuba to inventors and improvers. ${ }^{28}$

The case of entrepreneurs introducing foreign techniques, who could benefit from an importation patent in the parent state, was left to the discretion of the Governor General, after consultation the various Cuban intermediary bodies.

This rapid outline of patent law which develops on a world scale allows us to make some comments. The

22. Myriam Cottias, 'Esclavage, assimilation et dépendance’, Les Cahiers du Centre de Recherches Historiques, 40/2007, 27 April 2013. http://ccrh.revues.org/3394; DOI: 10.4000/ccrh.3394.

23. Édouard Sauvel, La propriété industrielle das les colonies françaises, Paris, Marchal Billard et Cie, 1881, p. 10.

24. Lionel Bently, 'The "Extraordinary Multiplicity” of Intellectual Property Laws in the British Colonies in the Nineteenth Century', Theoretical Inquiries in Law, 12.1, 2011, pp. 161-200.

25. Thomas Webster, The New Patent Law, London, Chapman and Hall - F. Elsworth, 1854, p. 37.

26. Coulter Moureen, 1991, Property in ideas: the patent question in mid-Victorian Britain, Kirksville Mo.;Lanham MD, Thomas Jefferson university press., p. 168.

27. Nadia Fernàndez de Pinedo, David Pretel and Patricio Sàiz, 'Patents, Sugar Technology and Sub-Imperial Institutions in Nineteenth-Century Cuba’, History of Technology, 2010, 30, pp. 46-62; David Pretel O’Sullivan, La economía Política del cambio tecnológico en la periferia europea, España 1826-1902, PhD, Universidas Autonoma de Madrid, 2012.

28. Collection legislativa en Espana, primer cuatrimestre 1849, LXVI, Madrid, Imprenta nacional, 1849, p. 107. 
adoption of these mechanisms depends on at least three types of factors. First, the industrial development of the territory in question, making patents necessary in the eyes of the colonials themselves. Second, the economic relations between the colony and its parent state help shape both the type of legal device adopted, and its implementation locally. Third, the political dimension of patents outside Europe and the United States: for countries coming to independence, the patent law appears as an element of sovereignty, even as a basic freedom. Native populations, however, seem excluded from this process.

These colonial patenting processes might be marginal from a quantitative point of view. If the data on patents issued in the parent state are relatively easy to obtain, they do not necessarily give a breakdown by the applicant's country of origin. It is also difficult to have reliable figures on patents issued in the colonies. The nineteenth-century basis of the Institut national de la propriété industrielle reports only six patents issued to residents of French colonies until 1844. This figure is risible in relation to the 17,007 patents (invention, importation, improvement) issued during the same period. Yet we cannot estimate the number of colonial patents that could be issued on the initiative of governor generals, as in Réunion.

It seems to be difficult to obtain figures for the United Kingdom and its colonies for the nineteenth century, but we do have data for the 1880s.

Table 3: British patent applications by country of origin, 1884 (Propriété industrielle, 1 Jan. 1888, p.5)

\begin{tabular}{|c|c|c|c|}
\hline Country of origin & No.pat & ons & $\%$ \\
\hline England & 12,356 & \multirow{3}{*}{13,511} & \multirow{3}{*}{79.0} \\
\hline Scotland & 901 & & \\
\hline Ireland & 254 & & \\
\hline The Indies & 40 & \multirow{7}{*}{113} & \multirow{7}{*}{0.66} \\
\hline [Australia] & 38 & & \\
\hline New Zealand & 16 & & \\
\hline [South Africa] & 10 & & \\
\hline West Indies & 6 & & \\
\hline Birma & 2 & & \\
\hline British Guyana & 1 & & \\
\hline United States of America & 1,181 & 1,181 & 6.90 \\
\hline European countries, excluding Great Britain & 2,211 & 2,211 & 12.92 \\
\hline Other non-European countries & 94 & 94 & 0.55 \\
\hline Total & 17,110 & 17,110 & 100.00 \\
\hline
\end{tabular}

In Spain between 1850 and 1880, patents applied for by resident Cubans accounted for no more than 1\% of all patents applied for by Spanish subjects. Yet according to Nadia Fernàndez de Pinedo, David Pretel and Patricio Saiz, around 4,000 patents were registered in Cuba between 1830 and 1880, accounting for 40\% of all patents granted in the Spanish Empire. ${ }^{29}$ As already suggested, with the example of Réunion prior to 1848 and the British case, it was as if there were two coexisting regimes of intellectual property rights: a parentstate regime and a colonial regime more adapted to local industry and to the circulation of techniques in transnational spaces.

From then on the question of the imperial nature of the international regulation of intellectual property at the end of the nineteenth century was posed from another angle. It was not so much a question of whether the Paris Union represented a way of sharing world intellectual property on an imperialist basis, as to how relations between the colonies and their imperial centres had evolved in this respect. In tackling this problem, we must keep two things in mind. First, the appearance at world level of new laws on patents, such as the 
Mexican reform of 1865, from the second half of the nineteenth century. Second, the end of the controversy over patents with the Great Depression in the 1870s. ${ }^{30}$ This is not the place to review the details of the discussions that took place in a country like the Netherlands which led to the pure and simple abolition of patents in 1869, but we must emphasize the fact that at the time there was no unified notion of industrial property on which to base a Western model.

\section{Controversies over patents under the Paris Union}

The emergence of discussion on the development of an international framework for patents was indeed inseparable from controversies at the national level. From the mid-nineteenth century, with the setting up of the Great Exhibition and the appearance of the free trade movement, the controversy on patents took place simultaneously at the local, national and international levels, and these levels of debate were interdependent.

\subsection{Towards an international system of patents}

Far from being limited to national disputes, the debate on patents even took place very early on at an international level thanks to the holding of international congresses. The emergence of the free trade movement in Europe helped to structure the abolitionist current, which was, paradoxically, one of the motors of the internationalization of patents.

In 1856, at the time of the international congress for customs reform in Brussels, Jan Akersdyck, professor of economics at the University of Utrecht and representative of the Dutch Society for the Development of Industry, demanded the suppression of patents considered as an unacceptable obstacle to free enterprise. ${ }^{31}$ Yet free traders were far from unanimous on the idea of abolition, as born out by the divisions among liberal French economists. Abolitionists were also put forward other measures to mitigate the dysfunctions of the patent, particularly at the international level. For example, there is the role played in Great Britain by the industrialist, sugar refiner, free trader, and president of the Liverpool Chamber of Commerce, Robert Macfie. Faced with competition from colonial and continental competitors, Macfie became an advocate of the abolition of patents or, at least, in favour of homogeneous legislation on an imperial scale, in order to prevent uneven competition. In 1862, he proposed a plan for a Patent Union to help standardize the legislation in different countries and to expropriate all patents after a deadline of three years in return for compensation paid to inventors. ${ }^{32}$ This plan was discussed in Ghent the following year then at the congress of the International Association for the Development of the Social Sciences.

Some abolitionists then supported similar compromise solutions. Although opposed to patents in principle, the famous inventor and arms manufacturer William Armstrong proposed their extension to all countries:

However great the advantages of uniform legislation in the countries which have approved patent systems, they would not be less in countries that do not recognize patents. In reality, it is irrefutable that they are the first to pay patents that the latter exploit. It is sometimes the case that the exoneration of countries that have no patents allows them to use the invention beyond a fair share. Without the chance to extend patents, free trade is an injustice, a contradiction in terms, only tolerable due to the great benefits generated by free trade. ${ }^{33}$

Free traders opposed to patents thus ended up defending a paradoxical position. The patent was certainly harmful since it created monopolies and hindered freedom of enterprise, but above all it was harmful because it was a handicap for countries with patent legislation in relation to those without. The distortion of the protection of inventor's rights disturbed competition. To correct this imbalance the alternatives were either a total suppression of patents or their adoption by all countries.

The British debate on the future of the patent fed into the debate for the standardization of national legislation. In 1872, the Parliamentary Select Committee on Patents, declared itself in favour of an assimilation of national laws. Following a delegation requesting Lord Granville to take measures to this end,

30. Fritz Machlup and Edith Penrose, 'The Patent Controversy in the Nineteenth Century', The Journal of Economic History, 10(1), pp. 1-29; Gabriel Galvez-Behar, ‘Controverses et paradoxes dans l’Europe des brevets au XIX ${ }^{\mathrm{e}}$ siècle', op. cit.

31. Congrès international des réformes douanières, réuni à Bruxelles: 22-25 septembre 1856, Brussels, Weissenbruch, 1857, p. 119.

32. Annales de l'Association internationale pour le progrès des sciences sociales. Première session, Congrès de Bruxelles, Brussels/ Leipzig/Paris, Lacroix et Verboeckhoven - Guillaumin, 1863, pp. 690-697.

33. Annales de l'Association internationale pour le progrès des sciences sociales. Deuxième session, Congrès de Gand, Brussels/Paris, Lacroix et Verboeckhoven - Guillaumin, 1864, p. 747. 
the next year Thomas Webster was sent to the Congress of Vienna on patents as a delegate of the British government ${ }^{34}$. The Vienna Congress of 1873 on patents was a strong moment for the supporters of industrial property rights. ${ }^{35}$ The origin of this congress rested on the United States' refusal to take part in the Great Exhibition in Vienna due to a lack of protection for foreign exhibitors. Stung by their participation in earlier exhibitions, the Americans blamed the Austrian authorities their vexatious behaviour in respect of their industrialists. ${ }^{36}$ Faced with the threat of an American boycott, the Viennese authorities took all measures to avoid frustration on the part of foreign participants; and also agreed to convene a congress on patents suggested to them by the Americans.

The main aim of the Congress was to find a way to regulate the question of patents, more or less definitively. In Vienna, the German delegation was large, thanks to Verein Deutscher Ingenieure, directed by Werner von Siemens, who was also vice-president of the Congress. His brother, William, presided over the meetings, and Carl Pieper, a Dresden patent agent, was in charge of the secretariat at this meeting, now in the hands of ardent supporters of patent law.

Thus it is not surprising to see that the Congress of Vienna consecrated patent rights. Although some critical voices could be heard, all resolutions adopted crowned the rights of the inventor. It is interesting to note that contrary to the resolutions of the British Select Committee on Patents, which basically justified utilitarian reasoning to maintain patent law, the first resolution of the Congress of Vienna asserted that the 'legal consciousness of civilized nations [demanded] the protection of intellectual work'. Thus, the congress made patent legislation a feature of the civilized world without any reference to natural rights. The protection granted by the patent established the payment of an inventor's work; it was also necessary that only the inventor (or his representative) should be granted the patent.

This greater level of protection meant real gains for society since all manufacturing secrets were avoided, and the complete publication of patented inventions, demanded by the Congress, would allow others access to technical information. Certainly it was necessary to avoid inventors' rights leading to malpractice. So the principle of prior examination was recommended by the Congress just like that of compulsory licences. As regards the internationalization of the patent, the Congress remained extremely modest although the law on patents was considered a civilizing element. Indeed, if the same treatment was demanded for foreigners as for nationals, the question of an international understanding was handled in a rather rapid and superficial way, leading to the adoption of a simple resolution. ${ }^{37}$ As for the question of the colonies, it did not figure in the resolutions.

The Congress of Vienna allowed the controversy to be closed on patents and provided a precise framework to improve these laws, taking English, American and Belgian law as well as the plan of the Verein Deutscher Ingenieure as reference points. France, which was not represented by a single delegate, was effectively left on the sidelines: for a majority of delegates the French law of 1844 was not suitable as a model. ${ }^{38}$ In a sense, the Congress reaffirmed the legitimacy of patents and called for their convergence, but simultaneously stressed the heterogeneity of national models.

The Austrian government did not seem inclined to follow up the work of the Congress of Vienna, and it was in the International Law Association (ILA), set up in 1873 in Brussels under the name of the Association for the Reform and Codification of the Law of Nations, that the discussion was followed up thanks to the British patent agent, Lloyd Wise, whose communication to the Congress of The Hague in 1875, initiated the debate. ${ }^{39}$ During the Congress in Bremen in 1876, the ILA decided to take the resolutions of the Congress of

34. Coulter, Property in Ideas ..., p. 174.

35. On the Vienna Congress see Thomas Webster, Congrès international des brevets d'invention tenu à l'exposition universelle de Vienne en 1873, Paris, Marchal, Billard et C ${ }^{\text {ie }}$, 1877; Yves Plasseraud, François Savignon, Paris 1883. Genèse du droit unioniste des brevets, op. cit., Chapter II.

36. See the article in the Scientific American of 23 December 1872: 'Constructors and patentees who have introduced their inventions in European countries have suffered grievous ill-treatment at the hands of the Austrian authorities, whose regulations on the subject of patents are, to say at least, not formed for the protection and reward of foreign talent and ingenuity' cited in Y. Plasseraud and F. Savignon, Paris 1883, op. cit., p. 126.

37. Revue de droit international et de législation comparée, 1874, p. 507.

38. No French figure appears in the list of members published in Thomas Webster's work, Congrès international des brevets, op. cit; Charles Lyon-Caen, 'Brevets d'invention. Congrès international de Vienne. Compte rendu de ses travaux', Annales de la propriété industrielle, artistique et littéraire, 1873, p. 377.

39. W. Loyd Wise, Assimilation of the laws and practice of various Nations, in relation to the protection of invention. 
Vienna as a working basis and to create a committee to draw up a draft for an international law. ${ }^{40}$ The latter was faced with the examination of the proposed amendment of the British Patent Act and, above all, to the adoption of the German law on patents in May 1877.

The theoretical foundations of the German law contrasted with their French counterparts. To resolve the deadlock posed by the issue of patent rights for inventions, as of the 1870s some jurists proposed the idea of a right of immaterial goods as distinct from a personal right or a real right. ${ }^{41}$ From this perspective the right of the inventor did not arise from his person, or from a contract between the inventor and society, but from the immaterial character of the invention. In this perspective, the invention comes from an immaterial idea that 'as soon as it [...] become part of our conceptions and our customs, become, as air and light, res communis omnium banishing by the same, the domination of the individual. ${ }^{42}$ Instead, if the genesis of the invention had an undeniably individual side, it also had a deeply collective trait and the right of patents had to take into account both the claims of the inventor and those of society. ${ }^{43}$

The German conception of patent rights thus expressed a will to construct a legal system to protect not so much the inventor as the community in general, concerned above all about the rights of industry. This imperative was all the stronger since, far from being eternal, the justification of the inventor's right must answer to social and historical constraints. ${ }^{44}$ The expectations of big industry and capital, which allow society to spread the benefits of invention, also had to be met. In contrast to the French tradition that tends to base the rights of the inventor on immutable principles, the German model was basically pragmatic and dynamic.

In its work the ILA thus resumed the perspective of the congress of industrial property convened in Paris in September 1878. During the Congress of Frankfurt in 1878, the patent committee, which included influential French jurists such as Bozérian, Gide, Lyon-Caen, Pataille, Huart and Pouillet, adopted twenty-one resolutions. These contrasted with the resolutions adopted five years earlier in Vienna. The questions of principle were dealt with less forcefully. Patent legislation was no longer considered as a feature of civilization even if a 'liberal law' must benefit, not only individual inventors but also commercial and industrial progress as a whole. More concretely, we should stress the need to establish a temporary patent together with an oppositional procedure. Besides, the resolutions specified the arguments for prior examination and priority conditions. Moreover, there was a call to abolish the exploitation clause. On the other hand, no resolution dealt with the colonies. ${ }^{45}$

So, despite the participation of French jurists, the work of the ILA drew up criteria opposed to the basic features of the French law: prior examination and the end of the exploitation clause. The drive for a rapprochement of patent legislation proved contradictory. As the risk of a victory for the supporters of its abolition diminished it turned out to be a 'conversation among the deaf' between different models of industrial property. It was up to the congress of Paris to try to overcome this contradiction.

\subsection{The 1878 Congress, a foundational moment}

The 1878 Congress dedicated to patents, trademarks, and industrial designs and models, was unquestionably a key step in the legitimation of industrial property and the search for a unitary right. It was supposed to be the French response to the Congress of Vienna, but it only emphasized the disparities among the various national models for the protection of inventions.

Almost 490 members took part in the Congress, yet effective participation was very uneven, especially as the

40. Association for the Reform and Codification of the Law of Nations, Bremen, 1876, p. 77.

41. The idea is defended by Josek Kohler in Annalen der badischen Gerichte, vol. 41, 1875, p. 100 ff. In Belgium, the jurist Edmond Picard defends similar ideas; see also Gustave Huard, 'De l'évolution du droit en matière de propriété intellectuelle', Annales de droit commercial, vol. 14, 1900, pp. 206-207.

42. Josef Kohler, Forschungen aus dem Patentrecht, Mannheim, Bensheimer, 1888, p. 117.

43. Josef Kohler, Handbuch des deutschen Patentrechts in rechtsvergleicher Darstellung, Mannheim, Bensheimer, 1900, p. 6: 'Die Erfindung ist nach ihrer Anlage wesentlich individualistisch; allein sie hat einen tief genossenschaftlichen Zug. Und so auch das Patentrecht'. We need a more detailed study to take on board the change in Kohler's thought in the last decades of the nineteenth century.

44. Kohler was influenced by the German École historique, see Hinnerk Bruhns (ed.), Histoire et économie politique en Allemagne de Gustav Schmoller à Max Weber. Nouvelles perspectives sur l'école historique de l'économie, Paris, Éditions de la Maison des Sciences de l'Homme, 2004.

45. Association for the Reform and Codification of the Law of Nations, Frankfurt, 1879, pp. 79-84. 
participants had to pay twenty francs for the right to vote: indeed, only eighty-six delegates took part in the vote debate on the patentability of chemical products. Even the international nature of the meeting was rather limited since only seventy-seven members registered were foreign nationals (under $16 \%$ of members). However, around ten governments were represented, in particular Germany and the United States. The British government did not send a delegate.

The organisers of the Congress of Paris affirmed their place in the wake of the Congress of Vienna. Nevertheless, instead of taking up again all its experience, they put back issues on the theoretical agenda which had already been discussed in Vienna. ${ }^{46}$ Two factors explain this: the desire to avoid being trapped in a theoretical framework from which France had been excluded, and the need to respond to the new challenges of French abolitionists led by Michel Chevalier, then professor at the Collège de France. ${ }^{47}$

So the first debate focussed primarily on the problem of the basis for inventors' rights. The recurring question of assimilating industrial property to property under common law again raised its head, but the lines of division on this issue did not align with the nationality of those taking part in the debate: while the Parisian lawyer refused to assimilate the rights of the inventor to property, the British delegate Jasper Henry Selwyn was not against. For those who wished to avoid dealing with the 'metaphysical' question of inventors' right, Eugène Pouillet, although at first reluctant to deal with the issue, forced the Congress to adopt a position of principle which turned out to be a monument to caution. ${ }^{48}$

The right of industrial inventors and authors on their works, or of manufacturers and traders on their trademarks is a property right; civil law did not create it: it only regulates it. ${ }^{49}$

The right of the inventor was thus not considered as only a positive right, even if all explicit reference to natural law, initially planned, was suppressed..$^{50}$

The 'metaphysical' questions touching on the definition of rights were rapidly scrapped, for fear that the congress would get bogged down in the issue. However, they reappeared during more concrete discussions. Debate on prior examination gave rise to tense discussion and the fear that the congress would turn out to be a resounding failure. Even before the congress started, several contradictory opinions had been expressed. Several reports submitted to the congress organizers favoured such a procedure However, a good number of reports by patent agents in particular, opposed this idea. ${ }^{51} \mathrm{~A}$ priori, on the eve of the Congress, the debate was still open.

Discussions were nevertheless subject to pressure from opponents of prior examination. Thus, denouncing the lack of probity of some American examiners, Pouillet declared prior examination useless: it subjected the inventor to the arbitrary power of uncertain administrators and conferred no definite guarantee for the patent holder. ${ }^{22}$ This position was considered mistaken and offensive by some foreign delegates, and several French agents and jurists voiced their fear of seeing inventors faced with examiners who while honest might not be sufficiently clear-sighted to judge new and certainly unexpected inventions.

The debate soon turned to the disagreement between French delegates and those of countries, such as Germany, which had opted for prior examination. The famous German jurist, Klostermann defended the principle of prior examination, arguing that a government had the duty to validate the truth of a right that it would then have to recognize. Schmidt, the Austrian delegate, voiced his concern that no international agreement could be reached if France and Belgium did not adopt this principle. ${ }^{53}$ Given the numerical superiority of French the principle was rejected. ${ }^{54}$

46. Congrès international de la propriété industrielle tenu à Paris du 5 au 17 septembre 1878, op. cit., p. 36.

47. Michel Chevalier, Les brevets d'invention dans leurs relations avec le principe de la liberté du travail et avec le principe de l'égalité des citoyens, Guillaumin et Cie, Paris, 1878.

48. Congrès international de la propriété industrielle tenu à Paris du 5 au 17 septembre 1878, Paris, Imprimerie nationale, 1879 p. 128

49. Congrès international de la propriété industrielle tenu à Paris du 5 au 17 septembre 1878, op. cit., p. 130.

50. The draft resolution stipulated that inventors' rights were 'based on natural law'. Idem.

51. In particular, E. Barrault, A. Cahen and D.-A. Casalonga. Casalonga proposes the implementation of a system of prior opposition.

52. Congrès international de la propriété industrielle tenu à Paris du 5 au 17 septembre 1878, op. cit., p. 190.

53. On Klostermann's position, see Congrès international de la propriété industrielle tenu à Paris du 5 au 17 septembre 1878 , op. cit., p. 188; on that of Schmidt, see ibid., p. 202.

54. Congrès international de la propriété industrielle tenu à Paris du 5 au 17 septembre 1878, op. cit., p. 206. The breakdown of the vote is not given. 
At that point the Congress needed a compromise so that the idea of an international conciliation, which was the aim of the meeting, did not disintegrate. So the demand for a prior and secret opinion was made and defended by the most determined opponents of prior examination, for exclusively strategic ends. In this way the Congress adopted a conciliatory motion, accepting that the applicant be granted 'a prior and secret opinion, so that he can maintain, amend or abandon his application, as he pleases'. ${ }^{55}$ Thanks to an optional opinion, the liberal character of the protection granted to inventors was safeguarded and a mechanism was planned to reinforce trust in the patent's validity. Plans for an international agreement remained, despite the tensions and intense differences that had appeared.

At that time the Congress thus needed a compromise so that the idea of an international conciliation, which was the purpose of the meeting, would not end up in pieces. So prior and confidential notice, was emitted and defended by the fiercest opponents of prior examination, for entirely tactical ends. Then the Congress adopted a conciliatory motion, accepting that an applicant be given 'a prior and confidential notice, allowing him to maintain, modify or abandon his application, as he sees fit'. ${ }^{56}$ Thanks to a optional notice, the liberal nature of the protection granted to inventors was safeguarded and a mechanism was planned to reinforce trust in the validity of their patents.

The overall tone of the Congress of Paris was conciliatory. The programme planned by the Congress of Vienna and the ILA was broadly taken up. On the other hand, it also dealt with some points on colonies and non-Western countries. The United States' delegate, Pollock, disputed this, fearing that Canada and Australia impose British legislation; a resolution defended by Admiral Selwyn demanded a common legislation for 'the mother country and its colonies':

It is desirable that in matters of industrial property the same unique legislation govern a State and its colonies, as well as the different parts of the same State. It is also desirable that the conventions of reciprocal guarantee for industrial property concluded between two States be applicable to their respective colonies. ${ }^{57}$

The proposal made by the French lawyer resident in Egypt stipulated that:

The international congress on industrial property expressed the wish that, with regard to non-Western countries that had not provided laws for the protection of industrial property, particularly with regard to Egypt, where there was a mixed international jurisdiction, diplomatic action should intervene so that the governments of these countries take effective measures to guarantee industrial inventors and authors respect for their property. ${ }^{58}$

When the Congress came to an end on 17 September 1878, its president, the senator Jules Bozérian, was pleased to see the emergence of 'an international commitment, that is, one which does not confine itself to any particular principle specific to any one country or another' ${ }^{59}$ Keen to safeguard the acquis of the Congress of Vienna and the ILA Congress, and determined to find the necessary consensus to preserve the international character of their initiative, the members of the Congress of Paris did not hesitate to make 'reciprocal sacrifices'. A break had well and truly been made.

One of the most striking aspects is the fact that industrial property was then constituted as a set of various branches dealt with from an international angle regarding patents, trademarks, designs and models and even industrial rewards. On the level of principles, industrial property was not entirely identified with positive right, without being assimilated to a natural right. The tones and nuances had changed. While the utilitarian and positive position was affirmed on the banks of the Danube, on the banks of the Seine, supporters of natural right had received a better hearing without questioning the basic consensus.

On the most concrete points on patents, the contrast between the resolutions passed in Vienna and Paris was even more perceptible: the obligation of prior examination disappeared in favour of secret notification; the exploitation clause was kept; and the principle of compulsory licences was rejected. Through these three points, it is indeed the French model which shows through, even if some French contest it and others defend it.

55. Congrès international de la propriété industrielle tenu à Paris du 5 au 17 septembre 1878, op. cit., p. 216.

56. Congrès international de la propriété industrielle tenu à Paris du 5 au 17 septembre 1878, op. cit., p. 216.

57. Congrès international de la propriété industrielle tenu à Paris du 5 au 17 septembre 1878, op. cit., p. 165.

58. Congrès international de la propriété industrielle tenu à Paris du 5 au 17 septembre 1878, op. cit., p. 244.

59. Congrès international de la propriété industrielle tenu à Paris du 5 au 17 septembre 1878, op. cit., p. 423. 


\title{
2.3. The negotiation of the Paris Union
}

The resolutions of the Congress of Paris still had to be realized at the diplomatic level. Here we need examine the period from the end of the Congress to the signing of the Treaty of Union on 20 March 1883. In fact this five-year period witnessed a significant reduction of initial ambitions. From the end of the Congress in 1878, the French Minister for Trade had been calling for the permanent commission appointed to implement the resolutions to ditch any points stressing disparities between different national laws.

When the international conference for the protection of industrial property met in November 1880, the draft drawn up by the French diplomat Charles Jagerschmidt turned out to be much more narrow than the conclusions of the 1878 Congress. ${ }^{60}$ The latter had adopted sixty resolutions, whereas the new draft could be summed up in around fifteen articles. As regards patents, all areas of possible disagreement had been omitted whether this was prior examination, the obligation to exploit a patent or compulsory licences. In addition, the topic of the harmonisation of legislation between parent states and colonies was not mentioned by Jagerschmidt's draft, just like the laws to adopt in Eastern countries. On 20 November, twenty states including the United States and Great Britain - agreed to the draft convention and final protocol, leaving the French government to convene a final conference.

On 6 March 1883 the delegates of around twenty states were again represented and met in Paris. If Germany and Austria-Hungry were absent, other states, such as Spain, Luxembourg, Romania and Serbia were represented. Right from the start nine states were ready to sign the proposed plan. Conference discussions were limited to the amendment of the final protocol in order not to delay the signing of the text itself. This took place on 20 March 1883, bringing together the delegates of eleven states: Belgium, Brazil, Spain, France, Guatemala, Italy, the Netherlands, Portugal, El Salvador, Serbia and Switzerland. Great Britain, then reforming its own legislation, waited until 1884 to join the Paris Union and the United States waited until 1887.

Its aim was twofold: to reinforce national regimes of intellectual property — in ensuring, for example, that each signatory state had a specific administration in the subject; and to promote the harmonization of national legislation. To meet the second objective, two principles were ratified: actors under the jurisdiction of signatory states were to be treated in the same way as national actors under the same jurisdiction and the institution of a priority right allowing an actor under the jurisdiction of the Union having filed a patent in his own country to file in another country of the Union.

Beyond these legal devices, the Paris Convention created an International Bureau of the Union for the Protection of Industrial Property under the aegis of the Swiss Confederation. The closing protocol of the Convention provides that:

\begin{abstract}
The International Bureau will centralize information of all kinds on the protection of industrial property and unite this in a general statistic that will be distributed to all governments. It will proceed to studies of common utility of interest to the Union and will draft, with the help of documents which will be provided by the various governments, a periodic publication, in French, on questions regarding the purpose of the Union. ${ }^{61}$
\end{abstract}

The adoption of the Berne Convention for the Protection of Literary and Artistic Works in 1886 led to the setting up of an analogous bureau. In 1893, the two Bureaux merged to become the United International Bureau for the Protection of Intellectual Property (BIRPI), which the historian Christopher May did not hesitate to call an 'early precursor to contemporary global governance'. ${ }^{62}$

The history of the genesis of the Paris Union allows us to better appreciate its impact. In comparison with the initial inspiration to obtain a convergence of national legislation in an almost cosmopolitan perspective, the Paris Union appears as a timid compromise, unable to deal with irreconcilable national models, and even as a renunciation. It nevertheless lays the foundations for an organization covering all domains of industrial property whose legitimacy it strengthens by granting it legal status under international law. In this debate among industrialized countries, the question of colonies was not the chief concern of the day - except

60. Ministère des affaires étrangères, Conférence internationale pour la protection de la propriété industrielle, Paris, Imprimerie nationale, 1880, pp. 26-29.

61. La Propriété industrielle, 1(1), 1 January 1885, p. 4.

62. Christopher May, 'The Pre-History and Establishment of the WIPO', WIPO Journal, 1, 2009, p. 19; for a different view on the early years of Bureaux réunis, see Justin Hughes, 'A short history of "intellectual property” in relation to copyright', Cardozo Law Review, 4, 2012, pp. 1293-1340. 
perhaps, for the question of trademarks. The Paris Union would deal with this problem gradually as it developed.

\section{The Paris Union, a global mechanism?}

We should note that the international regulation of intellectual property was not done in a day and that its extension was not given straightaway. If we only examine the domain of industrial property, we must note that the Paris Union underwent many series of revisions. There were four before World War I: Rome (1886), Madrid (1890), Brussels (1897, 1900), Washington (1911). Besides, a number of countries, starting with the Netherlands, were members of the Union without having complete law on industrial property. Finally, the question of assimilating colonies into the new mode of regulating industrial property was dealt with very gradually.

\subsection{Colonies in Pre WWI Paris Union}

We have to wait until the Rome Conference in 1886 for the question of colonies in the Union to be raised again. The regulatory project for the revision of the Paris Convention planned two measures in this regard. The first dealt with the accession of colonies to the Convention of Union. In this case, if the parent country in making the application, wanted to increase the number of votes which it can employ within the Union, this must be discussed as one of the first points on the agenda of the next amending conference. ${ }^{63}$ In this case the implicit issue was the weight of the imperial powers within the Paris Union. Yet the issue was adjourned following a discussion among French and British delegates. The second mechanism tended to publicize to 'an interested public, that of possessions [now] part of the Union due to the accession of their parent country' ${ }^{64}$ This proposal was adopted, despite the reticence of the Spanish delegate on the use of the term 'possessions', but here too the lack of ratification of the 1886 agreements left the issue pending.

It was taken up again in 1890 at the Madrid Conference. The International Bureau and the Spanish government hosting the Conference, tackled the topic of colonies and foreign possessions and proposed a double perspective in Arts. 10-11:

Colonies and foreign possessions

10. When one of the signatory States wishes one of its colonies or foreign possessions to be considered as belonging to the Union by the fact of the accession of the parent state, it must notify the government of the Swiss Confederation, that will give notice to all the others.

11. If, then the accession to the Union of a colony or foreign possession belonging to one of the signatory states, is requested for this colony or possession a deliberative voice in the conferences of Union delegates, this demand will be the first subject on the agenda of the next conference. ${ }^{65}$

Article 10 was adopted unanimously and allows the inclusion of colonial territories in the Union. By contrast, Article 11 which gave colonies an opportunity to influence the future of the Union was rejected following the French and British interventions. ${ }^{66}$ This Interpretative Protocol of the 1883 Convention of Union was only ratified by four countries.

The question of the role of colonies in the Paris Union was not taken for granted. Some colonial powers feared that the inclusion of their colonies in the jurisdiction of the Union might be interpreted as a recognition of sovereignty. They exercised caution at the Brussels Conference of December 1897, where the Spanish delegate was careful to specify that the colonies of Cuba, Puerto-Rico and the Philippines did not come within the jurisdiction of the Union. ${ }^{67}$ In 1900 , the British representative stipulated that only the United Kingdom of Great Britain and Ireland were covered. ${ }^{68}$ In 1911 things developed at the Washington Conference. This adopted, without much debate, an article opening up membership to the colonies, under the

63. Ministère de l'agriculture, de l'industrie et du commerce, Conférence internationale de l'Union pour la protection de la propriété industrielle. Rome 1886, Rome, Botta, p. 129.

64. Conférence internationale de l'Union pour la protection de la propriété industrielle. Rome 1886, op. cit., p. 131.

65. Procès-verbaux de la Conférence de Madrid de 1890 de l'Union pour la protection de la propriété industrielle, Berne; Jent and Reinert, 1892, pp. 141-142.

66. Procès-verbaux de la Conférence de Madrid, op. cit., p. 142.

67. Actes de la Conférence réunie à Bruxelles du 1er au 14 décembre 1897 et du 11 au 14 décembre 1900, Berne, Bureau international de l’Union, 1901, p. 202.

68. Actes de la Conférence réunie à Bruxelles du 1er au 14 décembre 1897 et du 11 au 14 décembre 1900, Berne, Bureau international de l’Union, 1901, p. 391. 
control of the colonies themselves or that of their parent states:

Art. 16bis. The contracting counties have the right to accede to the present Convention at any time for their colonies, possessions, dependencies and protectorates, [...] or any of them. For this purpose they may either make a general declaration, including all their colonies, possessions, dependencies or protectorates $[\ldots]$ in the accession, or expressly name those included, or confine themselves to indicating those which are excluded.

Under the same conditions the contracting countries may denounce the Convention on behalf of their colonies, possessions, dependencies, protectorates, or some of them. [...]

This declaration shall be notified in writing to the Government of the Swiss Confederation, and by the latter to all other Governments. 69

This measure took up Article 19 of the Berne Convention on the creation of an International Union for the Protection of Literary and Artistic Works, except that the formulation adopted at the Washington Conference was slightly different. ${ }^{70}$ It included protectorates and 'dependencies' to satisfy a British request anxious to integrate its dominions under the Paris Union. ${ }^{71}$

Yet we must ask ourselves why the inclusion of colonies and foreign possessions had occurred much earlier in the case of the Berne Union on copyright. We should recall that during the preparatory conference in 1885, this was clear to the delegates and the commission responsible for drafting the text. ${ }^{72}$ Moreover, from the adoption of the Berne Convention Spain, France and Great Britain took care to mention their colonies. The inclusion of colonial territories in the jurisdiction of international conventions on intellectual property was not conceived in the same way by [all] colonial powers depending on the type of intellectual property. Due to a lack of reliable data, we can only hypothesize. Doubtless counterfeiting work in colonial territories was reputed easier than that of industrial inventions, thus stimulating a move to take protective measures.

\subsection{The First World War and the emergence of a new IP regime}

The First World War ushered in a new era for the international regulation of industrial property. From 1916, while the bases for the inter-allied economic cooperation were being put in place, patent issues were the focus of discussions to weaken the German patent system that had become the point of reference in the prewar period. Among the many measures discussed, and which cannot be listed here, the plan, subsequently aborted, for an international central office to register patents was clearly one of the most significant. In the wake of the Great War, industrial property had become one of the levers of antagonism and economic cooperation for the great powers.

The Paris Union could have suffered from the conflict since all the pre-war treaties linking the warring parties had to be annulled. Nevertheless, its multilateral character and the presence of neutral countries made the Paris Union sustainable. In a preliminary note to the international conference which met to create a central office of registration in 1919, the French Ministry of Trade affirmed that:

It was thus necessary to proclaim that this Convention which France is proud to have initiated, constitutes an evident sign of progress in international relations based on justice and equity, [one which] it is desirable to see increasingly established, [thus] consecrating the international recognition of industrial property rights in a definitive fashion. ${ }^{73}$

It was not a question of challenging the existence of the Paris Union, but a question of going further down the road towards the unification of legislation. The unknown author of a note asserts that:

The new Union thus formed would complement and improve the large and rather basic Union created by the Paris Convention in 1883. Its realization was a new step on the road towards the unification of legislation that the French promoters of the Paris Convention had placed at the top of their agenda as the ideal goal to be reached and which would allow [...], in the future, the recognition of a unique international patent in all countries, guaranteeing

69. International Union for the Protection of Industrial Property, Actes de la conférence réunie à Washington du 15 mai au 2 juin 1911, Berne, Bureau international de l’Union, p. 255.

70. Actes de la $3^{e}$ conférence internationale pour la protection des œuvres littéraires et artistiques réunie à Berne du 6 septembre au 9 septembre 1886, Berne, K.-J. Wyss, 1886, p. 34.

71. The British delegation also hoped that the term 'dominion' would figure clearly in the text but this was not the case. The International Union for the Protection of Industrial Property, Actes de la conférence réunie à Washington, op. cit., p. 221.

72. Actes de la $3^{e}$ conférence internationale pour la protection des œuvres littéraires et artistiques réunie à Berne du 6 septembre au 9 septembre 1886, Berne, K.-J. Wyss, 1886, pp. 36, 53.

73. 'Avant-projet d'arrangement pour la création d'un Bureau central international d'enregistrement et d'examen des brevets d’invention’, sd. [November 1919], Archives du Ministère des Affaires étrangères, 429 QO/311. 
definitively the international protection of inventors’ rights in the most efficient way possible. ${ }^{74}$

In actual fact, the double movement of convergence and divergence was present right from the outset of discussions on the central office of registration, which in turn ended up being abandoned by its own promoters.

The congress of amendment in The Hague in 1925, testifies to this new industrial property regime. ${ }^{75}$ New international organizations came into play in the Paris Union: alongside the Bureaux in Berne, the League of Nations and, more importantly, its economic committee took part in the work of the conference, just as the International Chamber of Commerce (ICC) created in 1919. Moreover, the United States put great pressure on the Union to make it develop according to their own ideas. Together with Great Britain, they demanded the use of English as the official language and the introduction of the notion of reciprocity in the treatment of non-nationals so that the Union, under construction since 1883, would be based on the principle of simple assimilation. Lastly, the United States pushed for the abolition of the obligation to exploit in the countries which practiced it. If France was ready to do this, the principle was fiercely defended by Poland and other European countries on the grounds of their less developed industrial status. In the Hague, the influence exercised on the international regulation of industrial property was seen as a way to increase or reduce comparative economic advantage.

This was not an overwhelmingly important issue for the colonies, but they did start to become a stake, albeit minor, in the functioning of the Union. Territories under a League of Nations mandate were integrated to the Union thanks to a British proposal to amend Article 16bis of the Convention. Yet the director of the United Bureaux opposed the participation of non-sovereign states in the Union and proposed that Syria's involvement as a linked territory under a French mandate, be refused. ${ }^{76}$ When asked to explain this behaviour, the French ambassador in Berne stated that:

[M. Röthlisberger] expresses the concerns of the federal council, always keen not to allow the influence of the great powers in possession of world empires to increase in international organizations to the detriment of smaller states. ${ }^{77}$

In addition to such shows of concern we should add the initiatives of the United Bureaux to communicate directly with the industrial property offices of states under protectorate. For example, the Moroccan Office was contacted directly by the Berne Office to prepare for the upcoming Hague conference, and to defend amendments without any prior negotiation with France.

What was at stake for a colonial power such as France was to control the presence of its colonies in this international arena. It did so by firmly reasserting its privileges, particularly as regards sovereignty, but also by involving the colonies and the states under its control in decision-making. Syria and Lebanon refused to take part in the drive for an international registration of trademarks for fear of seeing the office of industrial property in Beyrouth lose key financial resources

\section{Conclusion}

During the nineteenth century, the patent laws were heterogenous, contradictory and their future could be considered uncertain because of the strong controversies which they provoked. Why did countries try to have their legislation converging in such conditions ?It is probably a key question for the understanding of the Paris Union. One part of the answer is probably the patent controversy itself. The process of the Vienna Congress to the Paris Union was a wau to close the controversy. Even if the new cosmopolitism of the late nineteeth-century has not to be neglected, we can consider that the international level offered opportunities to make national contradictions disappeared. Anyway, this project did not prevent the competition among national models of patent law. The emergence of tha Paris Union depended on a balance between the need for consensus and the willingness for assertiveness.

The simplistic response to question of the relation of empires to their patents is to summarize it as a process

74. Idem.

75. Union internationale pour la protection de la propriété industrielle, Actes de la conférence réunie à la Haye du 8 octobre au 6 novembre 1925, Berne, Bureau international de l’Union, 1926.

76. Letter from French Ambassador in The Hague to the French Ministry of Foreign Affairs, 14 November 1925, Archives du Ministère des Affaires étrangères, 429QO/37.

77. Letter from French Ambassador in Bern to the French Ministry of Foreign Affairs, 9 December 1925, Archives du Ministère des Affaires étrangères, 429QO/37. 
where the [imperial] centre imposes its vision of industrial property on its [colonial] peripheries. As we have seen, the implementation of patent law often responds to a need for a local regulation of economic and industrial colonial actors. Naturally, the latter turn out to be primarily colonials and the question of the role of autochthonous populations in this system is never raised. It is more complex in that it returns to the problem of their legal status within empires; only an in-depth survey of relations between native populations, inventive activity and intellectual property will give us a slightly clearer picture. Furthermore, it seems that the extension of the domain of patents, [only] becomes necessary when a territory has reached a sufficient level of industrialization. The idea that the patent is part of the baggage of imperialism is hardly applies before World War I. 